\title{
Narrative Works
}

Issues, Investigations, \& Interventions

\section{Chapter 5}

\section{Personal Essays about Hearing Stories of Helping}

\section{Mimica Tsezana-Hyman, Alexander George Katopis and Susan Santiago}

Volume 9, Number 1, 2019

Special Issue: A Narrative Works Monograph. Listening to Stories of Courage and Moral Choice: Creating Conversations about Inclusive Care in our Schools and Communities

URI: https://id.erudit.org/iderudit/1068125ar

DOI: https://doi.org/10.7202/1068125ar

See table of contents

Publisher(s)

Centre for Interdisciplinary Research on Narrative, St. Thomas University

ISSN

1925-0622 (digital)

Explore this journal

Cite this article

Tsezana-Hyman, M., Katopis, A. \& Santiago, S. (2019). Chapter 5: Personal Essays about Hearing Stories of Helping. Narrative Works, 9(1), 93-109. https://doi.org/10.7202/1068125ar
Article abstract

This chapter presents three personal stories about the experience of hearing stories of courage and moral choice within the context of family or work environments. These stories range from the retelling of experiences in Greece during the Nazi occupation to stories shared by senior citizens looking back at responses to discriminatory practices in Puerto Rico as they offered shelter and support to the author during Hurricane Katrina. In each case, the stories were either told repeatedly by relatives, or the stories echoed similar stories told in the past by family members. In each of these contexts, the listener describes the experience of learning about moral choices made in challenging situations that have helped to shape the choices that they continue to make long after hearing those stories.
All Rights Reserved @ Mimica Tsezana-Hyman, Alexander George Katopis, Susan Santiago, 2019
This document is protected by copyright law. Use of the services of Érudit (including reproduction) is subject to its terms and conditions, which can be viewed online.

https://apropos.erudit.org/en/users/policy-on-use/ 
SPECIAL ISSUE: A NARRATIVE WORKS MONOGRAPH

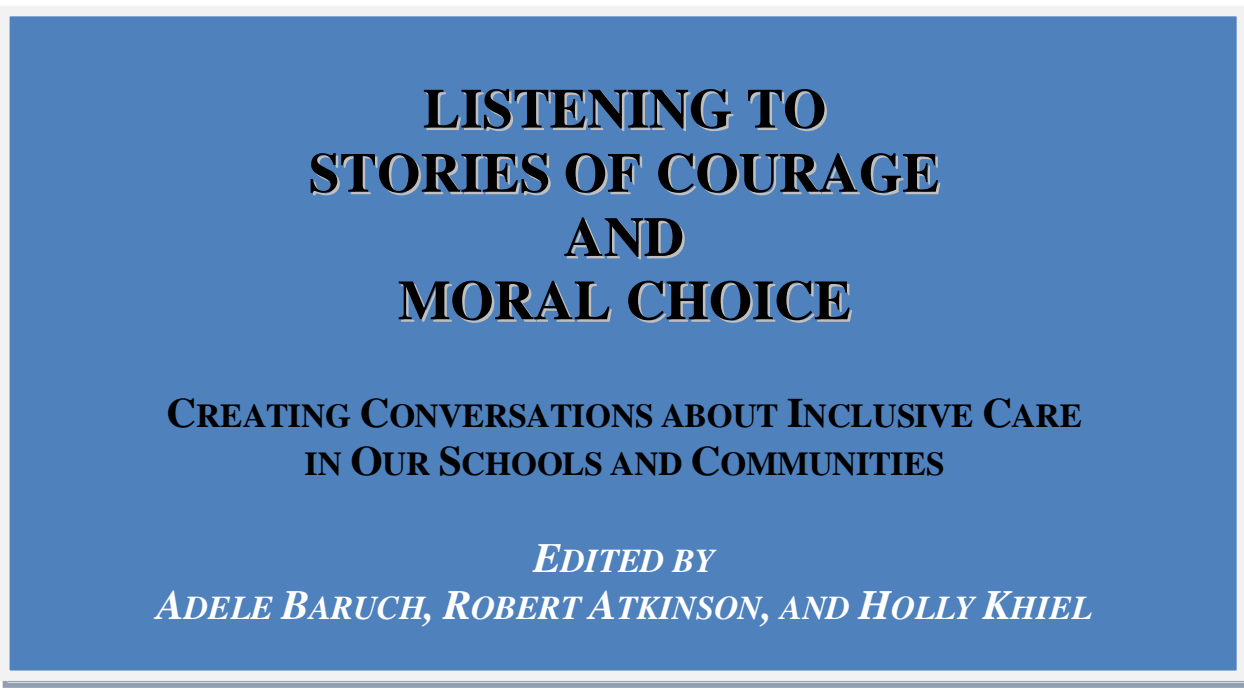

\section{Chapter 5}

\section{Personal Essays about Hearing Stories of Helping}

Mimica Tsezana-Hyman American Friends of the Jewish Museum of Greece Alexander George Katopis University of Southern Maine Susan Santiago Private Practice

This chapter presents three personal stories about the experience of hearing stories of courage and moral choice within the context of family or work environments. These stories range from the retelling of experiences in Greece during the Nazi occupation to stories shared by senior citizens looking back at responses to discriminatory practices in Puerto Rico as they offered shelter and support to the author during Hurricane Katrina. In each case, the stories were either told repeatedly by relatives, or the stories echoed similar stories told in the past by family members. In each of these contexts, the listener describes the experience of learning about moral choices made in challenging situations that have helped to shape the choices that they continue to make long after hearing those stories.

Keywords: Holocaust, Hurricane Katrina, Zakynthos, loyalty, forced sterilization, elders

NARRATIVE WORKS: ISSUES, INVESTIGATIONS, \& INTERVENTIONS 9(1), 93-109

(C) Adele Baruch, Robert Atkinson, \& Holly Khiel, 2019

Contact: adele.baruchrunyon@maine.edu 


\section{Mimica Tsezana-Hyman}

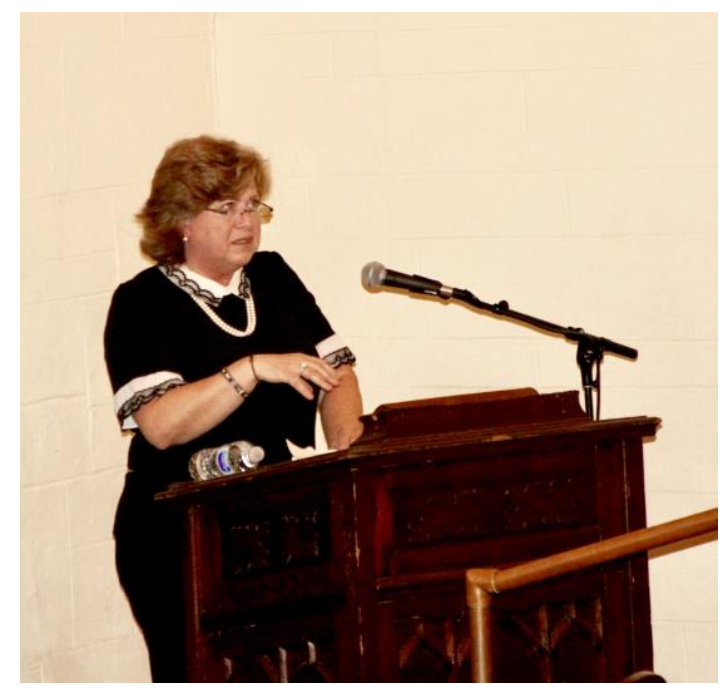

Mimica Tsezana-Hyman recounting stories heard from relatives. Photo: Dan Tooker.

I was born in Athens, Greece in the early 1960s. As I was growing up, I was told that I was different than other girls in the neighborhood, without any explanation why. There were certain ways of behavior that were expected of me and actions and activities that were allowed or forbidden to me. As I grew up, I understand that I was different because I was a girl brought up Jewish in Athens, Greece during the 1960s and 1970s in a Greek Orthodox society, in a country under dictatorship, controlled by men. When I went to study at Tel Aviv University in Israel, I felt different, because I was a Greek in an Israeli society. I was asked if I were Sephardic or Ashkenazi. All I knew at the time was that I was Jewish. Now I know that I am a Romaniote Jew. When I came to live in the United States of America, I had to add another subdivision to being a Greek Jew. Now I would have to decide if I were Orthodox, Conservative, Reform, or Reconstructionist. As the years went by, another bigger reason to my being and feeling different became quite clear to me.

As a Greek Jew, I am considered a rare specimen, as in a country with a population of approximately 11,000,000, there are only 5000 Jews left. Neither I nor my children would be here today if it weren't for the decision made by simple countrymen to hide their Jewish friends and neighbors about 68 years ago. My father and his family were among the 
275 Jews saved by Bishop Chrysostomos, Mayor Karrer, and the entire population of the island of Zakynthos.

When studying the Holocaust, the behavior of the local population of the Ionian island of Zakynthos stands alone among those of the rest of Europe. In many Holocaust museums you will find the writing, "You save one life, you save the world." The people of Zakynthos saved the world and our hearts. Should you visit the Jewish cemetery in Zakynthos, you will find evidence that there has been life in the island ever since 1445. You will find the grave of a very righteous rabbi from the 1400s, as well as the grave of a soldier of the army of Napoleon. And, of course, graves of the Jewish community of the island. The Jews of Zakynthos operated two synagogues and lived in full harmony under Greek law with their Greek Orthodox neighbors.

The island of Zakynthos was invaded by the Italians in 1941. Under the Italian Occupation, the Jews lived in fear, as did the rest of the people of the island, but they were not persecuted. In 1943, the Germans came to the island. By then, the people of Zakynthos had heard of the atrocities that the Germans had imposed, not only in other parts of Greece, but all around Europe. They had heard of deportations to concentration camps, of massive executions, gas chambers, and ovens where bodies were burnt dead or alive. They knew that the Jews more than anybody else were in grave danger. The German officer assigned to Zakynthos was called Berens.

One morning at gunpoint, Officer Berens assured Mayor Loukas Karrer that his life was in immediate danger. It would be the list with the names of the Jewish population of the island or next time it would be his gun that would speak instead of his mouth. The Mayor conveyed the news to Bishop Dimitrios Chrysostomos. Having made up their minds, they advised the Jews of the island to hide in the villages outside the city and asked the residents of Zakynthos to protect them.

Officer Berens received the list he requested, in both German and Greek. There were only two names written on it: Bishop Dimitrios Chrysostomos and Mayor Loukas Karrer. Through further negotiations, they were able to save all 275 Jews. The Germans respected Bishop Chrysostomos, as he had studied in Munich and spoke German. Some say that he even had met Hitler himself at the University of Munich.

The announcement came from Germany saying, "The Jews of Zakynthos could remain on the island under the personal supervision of the Mayor and Bishop." When I asked my father who hid our family during the German invasion of the island, I thought the answer would 
consist of one name. Instead, my father's answer was "The Sarakini family, the Roumelioti family, the Mbafaki family, the Pastras family, and the Hamouza family." When I heard the second name I was surprised. When I heard the fourth name, I was shocked. After the fifth name I was moved. The events that we hear happen to other people, never touch our feelings the same way as they do when they happen to someone so close to us.

I asked my father to tell me some stories that took place during the German Occupation in Zakynthos. Here is one of his stories:

When the Germans would line up the men to impose forced labor on them, the Christians would go next to the Jews that were standing in line, and gently direct them to the end of the line. This way, as the Jews hopefully would not get a turn to work, direct contact between Jews and Germans was avoided.

Another story is the following: While hiding in the village of Gaitani, at the home of the Sarakini family, one day the German soldiers came to search the houses in the village. They were looking for me to put them to work for them. The house had four rooms and I happened to be in one of those rooms at that very moment. The family had a little black dog. It was very interesting to see that the dog was quiet while the soldier searched the first, second, and third room, but started barking at the soldier preventing him to enter the fourth room in which I was standing behind the door, trembling with fear. The dog made so much noise that it drove the German soldier away. That day, that dog saved my life.

The people of Zakynthos were unlucky to be hit with a massive earthquake of 6.5 on the Richter scale that leveled the entire island in 1953. At this point I would like to mention that the first ships that came to the island with medical and humanitarian help were the ones of the Israeli Navy. "Israel offers this help to the people of Zakynthos, as a sign of appreciation, due to the fact that they saved the Jewish community of the island during the German Occupation, through their bishop and mayor" (Stravolemos, 1988).

After the earthquake, all the Jews of the island moved either to Israel or Athens. When the island was rebuilt, the Jews of Zakynthos, as an expression of their gratitude towards their saviors, paid for and donated their personal labor to replace all the windows of the Saint Dionysios Cathedral. Saint Dionysios is the saint that protects the island of Zakynthos. At the site of the Synagogue, statues stand tall commemorating the heroism of Bishop Chrysostomos and Mayor Karrer. 
About 9 years ago, a documentary on the story of the Jews of Zakynthos during World War II was made by Mr. Tony Lykouressis (2001), called Song of Life. In that film, members of my family and other survivors are talking about how they were saved and what life was like in those days. The community of the island of Zakynthos, of which $100 \%$ of the Jewry was saved, is compared to the Jewish community of the island of Corfu, of which $95 \%$ of the Jewry perished. In the documentary, the only two sites that stand proof today that Jewish life existed on the island of Zakynthos were visited: the site of the synagogue and the site of the Jewish cemetery.

For the past several years, in cooperation with the American Friends of the Jewish Museum of Greece, I have been organizing presentations consisting of the screening of the documentary Song of Life and of my speeches about my father's memories and experiences on the island of Zakynthos during World War II.

It has been observed that history repeats itself. Should there ever be a similar situation in one's lifetime, in which one will be asked to provide information that will destroy other people's lives, I would like to believe that through my speeches and presentations, I may also have done my part in contributing to the future generations of humanity, the encouragement, and the tools of how to remain moral under stress. I strongly believe that kindness is a lot more contagious than hatred. Through my presentations, I would like to believe that I give back to the people of the island of Zakynthos the appreciation and acknowledgement of a great ancestry.

\section{Alexander George Katopis (in collaboration with Angela Katopis)}

This story will be like a fable where neither exact times nor exact locations are known in detail. The events that I use have come to me through my mother and my grandmother and both of them were not very specific about the exact times or places. However, I know that my grandfather, Tilemachos, was born in 1901 at the port town of Patras in Greece, where he lived and prospered. Once he was established in his business, in his late forties, he married my grandmother, who was the daughter of another merchant (my great-grandfather) whose store was nearby. These two men had known and respected each other from many years of business interactions. Just before their marriage they had to move to Athens, to the great chagrin of my grandmother, who loved Patras, so 
that my grandpa could take over the management of the fabric importing and distribution business and shop owned by a Jewish family called Asser. He died at the age of 62 in the apartment where my mother was born and raised and where I spent quite a bit of time as a child every year.

Tilemachos Economopoulos was a very religious Greek Orthodox Christian man, politically conservative, and a dedicated Greek patriot, having been enlisted and served in the disastrous for the Greeks war against Turkey in 1921. My grandfather was as loyal to close friends and relatives as he was to his country. The stories of his acts of loyalty are many and colorful and they were narrated to me by my grandma, often expressing misgivings for my grandpa's extreme loyalty, but always with an unmistaken undercurrent of respect and admiration for his character, the most intriguing one being that of keeping his promise to a terminally ill close friend of his that he would take care of and help his friend's mistress after his friend's death. At that time, he was married for some years to my grandma and apparently the mistress that he had to take care of had some significant class differences with my grandma.

Tilemachos did not hesitate to keep his promise to his deceased friend by visiting the ailing widow of his friend regularly, but secretly from my grandma, and helped her with moral support and finances during the rest of her life. The regularity of these visits did not go unnoticed by my grandma who insisted to know the truth. Once she did, she realized that her husband's loyalty made it impossible for him to go back on his word to his friend, and she gave him her support.

Stories like the previous one abound about my grandpa, many times helping friends and relatives against the rational advice of his wife, even though he was very much in love with her and admired her immensely. These stories extend from the generous support for the mother of his wife during her late years of life to the financial and moral support to one of my great uncles who was the black sheep of my grandma's family because he had wrecked the estate of my greatgrandfather due to personal weaknesses. I have to stress at this point that the sense of loyalty to one's extended family was a very common and dominant cultural attribute of all the Greek people. After all, at the genesis of Greece, the Hellenic city states were an affair of few extended families. It is unique and no accident that the Greek noun for "nightmare" is simply the first name of a Greek that displayed the ultimate disloyalty to his Spartan clan, betraying them to the invading Persian armies. Efialtes was his name and "efialtes" to this day means "nightmare" in the spoken Greek language. The brutal and oppressive Occupation of Greece 
by the Turks for 400 years only enhanced this attitude so that the Greeks could survive and maintain their faith. Consequently, at the time of my grandpa, the middle of the 20th century, one's loyalty to the extended family transcended political beliefs, class separations and other misfortunes.

However, the most striking act of loyalty by my grandfather is his support for the Jewish family of the owner of the business where he was working. The story is rather simple and typical of the behavior of some Greek families during the Occupation of Greece by the Germans in World War II, even as many others cooperated with the occupying Nazis. As it has been narrated to me, soon after the Occupation of Greece by the Germans and the beginning of the persecution of the Jews, Mr. Asser decided to flee with his family to a safe hiding place (nobody knows the exact place, but it seems to me that they may have followed the remnants of the Greek army and the King of Greece to Egypt, which was a British colony or protectorate at the time). In doing so, he had two major concerns, namely, first to hide the considerable savings he had amassed which at these times consisted of gold and precious stones (mostly diamonds), and second to make certain that his business was maintained during the German Occupation of Greece. The latter was easy to accomplish. Mr. Asser was the mentor of my grandpa since his teenage years when he hired him as a helping hand in one of his stores in Patras, and through the years he had moved him through all the ranks of his business, eventually making him manager of his store in Patras. Because of this relationship, it was only natural that Tilemachos would assume control of the whole business in Greece, and while the Germans were in power he would appear to be the owner of the business. His obligation was to sustain the business and have the profits made available to the owner's family. All the appropriate legal papers to this end were drafted and summarily executed.

However, the hiding of the fortune of the Asser family was another matter altogether and even more dangerous. Already Greek acquaintances of my grandfather from Patras were calling him "The Hebrew" because of his close not only professional but also social association with the Asser family for all his adult life. In fact, it was expected upon the disappearance of the Asser family that the German Gestapo would call upon my grandfather first and search his house. Tilemachos was not the man to let his adopted family down. As head of his own family, he decided that the safest way of securing the Asser fortune was to hide it in the house of his sister who was a reclusive 
intellectual widow. In fact, it was hidden in a receptacle in the floor of his sister's house under the wood-burning stove, as my grandma found out after the liberation of Greece and the return of the Asser family. After all these preparations and agreements were completed, the Asser family went into hiding, having contact only with my grandpa.

My grandpa was not equally lucky, though. Upon the disappearance of the Asser family, as it was expected, the Gestapo paid a visit to my grandpa's Patras store, but they found the business transfer papers okay and they went away. However, it appears that other people from Patras talked about the close relation of my grandpa with the Asser family and the Gestapo reappeared at the house of my grandpa and took him to their infamous interrogation center. My grandpa never described in detail what happened to him in there, but then again, he never described in detail the horrible things he saw during the campaign in Asia Minor. These unpleasant events and experiences were not appropriate for angelic female creatures like my grandmother, according to him and the mores of his age. The only thing that he told my grandma Vaso was that he was held at the Gestapo detention center for two weeks and he was beaten regularly. Somehow, he managed to persuade his captors (after all, he was an excellent salesman) that he had stolen the business from the "cursed Jews" and possibly bribed his way to freedom. He cleverly and faithfully ran the business on his own for the rest of the three years of Occupation, and then the liberation came, along with the safe return of the Asser family. Although many Greek families helped Jewish friends to hide and escape the concentration camps during the German Occupation (and I do recognize that many cooperated with their occupiers) it was not atypical for these families to have difficulties to return the valuables that their Jewish friends had entrusted them with while in hiding. They felt that they had put their lives at risk having endured the German Occupation, the murderous famine of 1942, and they ended up liberated but totally financially destroyed. What is wrong in having some material assistance?

Such arguments were not even considered by my grandpa. As soon as the Asser family came back, he remade the papers to pass the ownership of the business back to Mr. Asser, and he delivered to the Asser family their valuables from his sister's home. For many years after this event, his wife would pull his leg for all the gold that his Jewish friends gave him or his sister for all their troubles. Tilemachos never blinked an eye and never stopped being close to the Asser family. They shared their business and all of their business knowledge with him. 
The story has a happy ending because upon the death of Mr. Asser, Senior, and due to the business inexperience of his sons, my grandpa was made a minor partner of the business and was appointed as the general manager of all its operations in Athens. This allowed him to be prosperous doing the work he liked for the rest of his life. These were the unique years when a promise made was for life and the need for lawyers minimal.

Many times I have heard my grandma marveling and wondering what made my grandpa behave so altruistically towards the Asser family and ending up always stating that he was an exceptionally kind man and a good Christian. I believe that he was both of them, but I also believe that his altruism was the result of one of his main personal attributes, namely, his sense of loyalty.

Now, it is my thesis that the combination of family loyalty and commitment to one's "personal honor" result in selfless acts of helping a select group of others, and in our culture, we call it altruism. In fact, this thesis is supported by the responses of people who have acted altruistically when they were asked why they felt and acted this way. The typical answer is that "I had to do it," as if this was their duty or a necessity even if it endangered their life. They seem to dissociate the morality of their action or their personal risk from the action. They almost say that they were "programmed" to do it. They do recognize the moral value of their act, but they do not appear to connect it to their motivation for the specific action. Consequently, if my thesis is correct, the behavior of my grandpa would have been expected, provided that we can find a reasonable explanation of how a devout Christian came to consider a Jewish family as his own and extend to his adopted family his inbred sense of family loyalty.

My grandpa, in his teenage years, understood that he was not doing well at school. He asked his father to find him some work in Patras, and he was accepted as a junior clerk at the shop of the Asser Company. Tilemachos attached himself to Mr. Asser for all his learning needs and he worked very, very hard to gain his acceptance and approval. Mr. Moises Asser, having gotten married late in life (not so accidentally, in my opinion; my grandpa married very late in life, too) and having very young children was longing for a grownup son to whom he could pass on his wisdom. Tilemachos was more than primed to absorb any knowledge he could get. I only had to change the years, names of schools and places with the ones that I have encountered in adolescence to understand the bond of my grandpa to the Asser business and family as they are so 
similar to mine with Elan and my counselors there that they have changed my professional life's direction.

My grandpa learned with amazing speed for a school reject as he acquired technical facts for the fabric technology that the Asser business was involved with, as well as the accounting and management skills necessary for running the business. This, along with his steady rise within the ranks of the clerks in the Asser store, must have given him great satisfaction and made him feel even more indebted to his mentor. His excellent professional relationship with Moises Asser, as well as the enlightenment of the Asser family, made it inevitable that he was invited to the Jewish holidays and participated in many Jewish customs. He got to know and socialize with the entire Asser clan. This may have alienated him from some parts of the Patras society, but it must have enhanced the strength of his bond with his newfound Jewish family. This family was much younger than his parents to whom he was the youngest of thirteen children, introduced him to a finer way of living, and exposed him through their commercial connections to their other European partners. He was sent to Milano, Italy, to enhance his understanding of the commerce of fabric, and he learned Italian in record time. He started calling the relatives of Moises not by their last names but by the first names preceded by relation adjectives, like "Aunt Behorula" or "Cousin Mino." I believe eventually he came to accept the Assers as his own family with some "strange" characteristics, like their religion, that had no bearing either to his esteem of them or his caring for them. I have seen similar behaviors in Greece based on political differences as I was growing up. Eventually, a "right winger" will consider his "socialist" relative as having a strong "habit of weakness," which does not prohibit him from loving his relative, being proud of him as a human being and bestowing upon him the family loyalty.

Consequently, my grandpa's formative years and experiences made him a member of the Asser family, which he honored and gave his loyalty to for the rest of his life. This is the only way that one can explain behaviors of my grandpa as they were related to me by my mother in amazement and with a small degree of resentment, such as going to the synagogue in Athens on special days and lighting the Jewish candles to honor the memory of Moises Asser, while attending devotedly the Christian liturgy the next day. How else can one explain that he had to exchange brown eggs on Passover with his Jewish family over the protestations of his wife for the rest of his life? This was the man who insisted that his daughters go to the most austere segregated religious 
school in Greece while at the same time expecting them to call "aunts" the female relatives of Moises. His explanation, "We are all creatures of God no matter how we call Him," was very advanced for his time and not easily understood either by his children or his wife.

I have listened to my mother recite these altruistic stories of my grandfather to me ever since I can remember. Listening to these stories and others throughout my early childhood and into my late adolescence, I believe that they have created a significant impact on my values, morals, beliefs, and even personality. While environmental, economic, and other factors have shaped who I am today, a huge influence has been rooted in the stories of my grandfather and his honorable life-risking behaviors to help protect the wellbeing of others. Hearing these stories has made me not only look up to my grandfather as an idol, but also has made me want to strive toward his fearless, brave, and altruistic behaviors so that other members of my family can be proud of me but also carry on my grandfather's noble reputation from generation to generation.

The previous analysis, I believe, conclusively established the family bond that my grandfather had established with the Asser family, and hence, what he did for them was nothing more than what he had to do. His commitment to honor just helped him in doing what he had to do by making it easier for him to overcome his fear of the German Gestapo. In our "Anglo" culture we may call him an altruist but I prefer his native

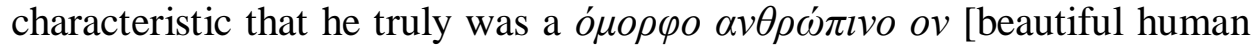
being], as my grandma Vaso always called him.

\section{Susan Santiago}

Nearly 5 years have passed since I experienced Hurricane Katrina in southern Florida. I was a geriatric counselor-in-training enrolled in a clinical psychology doctoral program. I was in my mid-30s, and a fish out of water in Florida. My intention was not to live la vida loca in southern Florida, but rather, I wanted to make a concerted effort to make it on my own after simultaneously earning a master's degree in counseling psychology from a university in the Midwest, and getting a divorce. I arrived in Florida full of energy and motivation to succeed. I was unencumbered save for the company of my beloved cat. In my quest to become a gerocounselor, I deliberately situated myself where I could practice the art of counseling with older adults, and in doing so I inadvertently situated myself in the trajectory of what was to become one 
of the worst hurricane seasons in southern Florida since Hurricane Andrew.

I met Doña Antonia in June 2005 at my internship site, where I served as her gerocounselor. Prior to Doña Antonia, the majority of my clients were Euro-American. I am second-generation Puertorriqueña whose parents migrated to the United States during Operation Bootstrap in the 1950s. Doña Antonia is first-generation Puertorriqueña who migrated to the United States during the same time period. She was a return client. She was originally seen by a male counselor who was not sensitive to or respectful of her cultural values and traditions. She was labeled with the diagnosis of bipolar disorder. In reviewing her clinical notes, I found no evidence that a thorough understanding of her culture was taken into account to explain Doña Antonia 's behaviors and beliefs. On the one hand, as her counselor, I developed a therapeutic relationship following the protocol of the agency, but on the other, as a Latina in the presence of an older Latina, I developed a sense of longing to understand where she had been and what life circumstances had brought her to the agency for a second time. This was the beginning of the myriad ways I embraced one of life's murky dichotomies, the role of professional relationships versus personal relationships. This murky dichotomy is perhaps most prevalent when working with older adults who were socialized to not discuss their personal problems with strangers, let alone a mental health professional.

I realized that if change was going to take place in the lives of my clients, I had to tread the line carefully between the professional and the personal, because I felt a strong connection with each of them. My clients were older women in prefabricated homes, relying on social security as their primary source of income. Most were widowed and had several uninvolved adult children living in the surrounding area. Although on different paths, my clients and I were on a similar journey to maintain our independence and to persevere despite the odds. And yet, these older women were most impacted by the succession of hurricanes. This story is in honor of all the clients to whose life story I had the privilege to listen. These women had the remarkable ability to embrace contradictions, to reveal what is concealed about the beautiful/ugly aspects of life. They demonstrated how ambiguity is a part of the landscape of human development and social relationships. Acts of intervention not only took place during therapy, but during the succession of hurricanes that summer, when we were all humbled by the force of a natural disaster. We entered each other's lives, built multilayered relationships, and made each 
other more human than we would have been had we not experienced Hurricane Katrina. With little clinical supervision, I tried to serve my clients during the succession of hurricanes during that fateful summer. I will share my experience of inclusive caring with Doña Antonia .

Translating my experience of living in Florida during Hurricane Katrina is anything but literal, because translation would require the voice of Doña Antonia in complementary fashion. She knew then that I would share the message behind her story and of our time together during Hurricane Katrina. Her strength, presence, and wisdom remain a significant part of me. Giving voice to the memory of Hurricane Katrina represents a haunting paradox of a moment in time and of a timeless connection that Doña Antonia and I will forever share, even if we never see each other again.

On August 26, 2005, Hurricane Katrina made landfall in southern Florida. I was determined to hunker down in my condominium, but Doña Antonia insisted that I stay with her. The realization that another hurricane was going to make landfall had dawned on me and caused a sense of desperation. I knew that the majority of my clients had not recovered from the previous hurricane, nor had I. I accepted Doña Antonia 's offer, despite knowing that I was blurring the line between client and therapist. I took a leap of faith, trusting that everything would work out. I gathered my 13-year-old cat along with a few personal items, and quickly drove to her home. She waited outside for me, and as I drove into her driveway I immediately felt as though I had been transplanted back to the island of Puerto Rico. I realize now that this feeling I had was one of nostalgia for my parents' home. She asked me to place my cat in one of the bedrooms, later telling me that she had cat allergies. We sat in silence as Hurricane Katrina made landfall. The flickering candles and Doña Antonia 's windows danced in unison to the force of Katrina's wind.

Time was difficult to tell. We talked, not like client and counselor, but she as a keeper of meaning and me as the seeker of knowledge and wisdom. I asked Doña Antonia to continue telling one of her memories of living in Puerto Rico that she had not finished during one of our sessions together. Doña Antonia shared how the most significant event in her life was when she returned home on college break to find that her best friend was coerced into getting sterilized. This was a U.S. government sponsored program that coerced Puerto Rican women into being sterilized between the 1930s and the 1970s, when approximately one-third of Puerto Rico's female population of childbearing age had undergone the 
operation. Doña Antonia said the words "sterilization" and "la operacion" (the Operation) were used interchangeably. I am privy to background information that I learned from my parents about the sterilization program in Puerto Rico. It is important to understand the eugenics movement in the United States and its territories. A number of "progressives" at the turn of the last century acted as agents for what they viewed as positive social change in the name of science, though the form and direction of change were often taken for granted as being morally "right" at the time. This operation was performed predominantly on women who were mentally challenged or poor and uneducated. Doña Antonia shared with me how this was the case in certain villages in Puerto Rico. After she and Myrna graduated from high school, Myrna left Ponce to live with her boyfriend in Salinas. She had two children within two years. Meanwhile, Doña Antonia was away at college, working toward a degree in social services. She was dating someone seriously but was not ready to get married. Her fiancée was studying engineering at the same university. Myrna stopped corresponding with Doña Antonia , and so she never knew that she had children.

Doña Antonia came home during breaks and asked for Myrna, but her parents never told her about the children, revealing only that Myrna was living down south with her boyfriend. Two years passed, and Doña Antonia was home again on break when she ran into Myrna at the town plaza in Ponce. Myrna had her two infant children with her. Doña Antonia described the reunion as one in which they simply picked up where they left off, like happy young women, except Myrna had two babies in tow. Doña Antonia is humble and intuitive, so I suspect that she did not put on airs for being away at college. She described how Myrna finally shared with her the process of sterilization, and how she was coerced into it because they (the authorities) said that it was the only acceptable form of birth control. Myrna never questioned the health authorities. Doña Antonia was furious and embarrassed that this had happened to her best friend. She had heard of such stories, but they always seemed so far away from her reality. She said that this was how the U.S. government treated the inhabitants of the island of Puerto Rico. I recall hearing similar sentiments from my parents when they spoke of living on the island during the 1940s and 1950s. So I put the pieces of the puzzle together.

Doña Antonia shared with me how learning what happened to her best friend hurt her soul very deeply. She wanted only to protect Myrna and she felt as though she had abandoned her friend when she went away 
to college. Now, in hindsight, she knows that this was not a rational thought, but during those times, friendship had an entirely different connotation than it does today. Doña Antonia seemed to find solace in knowing that she would graduate from college soon, and that she would find a way to situate herself and Myrna and her two children in the United States. Her boyfriend already had family living in New York. It was just a matter of time. Then, Myrna's boyfriend left her and their children. She had no other place to go and asked if she could stay with Doña Antonia 's parents. I got the sense that this was not an accommodation that Doña Antonia 's mother wanted, but apparently she acquiesced. To provide for her children and pay room and board, Myrna found piecework to do while Doña Antonia returned to college.

I worried about sounding like a counselor, but I had to ask Doña Antonia what impact all of this had on her. She reiterated that because she was away at college she viewed the interventions of the United States through an entirely different lens than did many islanders who were not fortunate enough to attend college and/or to be exposed to the island politics. She said that the reason she was embarrassed for Myrna was that she knew that poor, uneducated women on the island were considered feebleminded. When U.S. health officials came to the island under the moral obligation to control the population, they were never questioned about the rationale behind sterilization or the reasons for testing the pill on poor, uneducated Puerto Rican women. Doña Antonia said that it was like the dirty little secret that no one talked about. I am privy to what she was alluding to because my parents told me about it, but that did not make it any easier to listen to.

Doña Antonia said that what took place on the island between the 1930s and 1970s created a psychological wound that runs deep, affecting generations of Puerto Ricans. She said that because the history of Puerto Rico is so convoluted, Puerto Ricans are not able to fully understand why the world sees them through stereotypes and caricatures. This is why what happened to Myrna was so important to Doña Antonia, because she wanted to expose what was happening, but never felt empowered to do so living on the island. She wanted to make change, but realized that she could not do so while living on the island of Puerto Rico, so she made good on her promise and left for the United States in 1956.

Doña Antonia, Myrna, and her two children landed in Brooklyn, New York, where Doña Antonia's fiancée was already working as an engineer. She stayed with a family member. She describes her initial experience of America as one filled with excitement. She was educated 
and pretty fluent in English, so she managed to find employment at a local social service agency. Myrna, on the other, hand struggled for a while to find employment and finally did as a seamstress at an undergarment factory. Doña Antonia married her high school sweetheart later that year. They were married for fifty years when her husband died suddenly in 2000. Ironically, they were not able to have biological children, so they adopted two daughters. One daughter still lives in northern Florida, and is a nurse practitioner, and the other daughter lives in New York.

Like a cautionary tale, Doña Antonia's story addresses the dominant forces of representation and power that reflect issues surrounding womanhood that are nuanced and require attention. Her story continues to infuse me with the emancipatory spirit of inclusive care and stewardship that I witnessed after Hurricane Katrina made landfall in southern Florida, because her story is embedded within a network of storytelling that takes place among Puerto Rican elders. This generativity enlivens me and compels me to find ways of sharing the reality of women in Puerto Rico during this historical period. Doña Antonia understood the interplay between a natural disaster and the strength of the human condition much better than I could ever imagine.

My culture is beautiful, and I believe that it is very important to keep as much of it as I can. Being in the presence of Doña Antonia served as a reminder of the cultural values my parents instilled in me, particularly those of humility, respect, and confianza (trustworthiness). Doña Antonia said that Myrna was the strongest woman she had known, because she struggled beyond marginalization to a place where she could stand firmly upon her inner strengths, despite forces that tried to negate her value as a woman and as a human being. My duty is to find ways to lend this story to women who realize that they struggle against unhealthy forces that are still pervasive, despite the civil right movement and the women's movement during the 1960s and 1970s. Listening to, and now remembering, Doña Antonia 's story demonstrates for me that the various forms of pain that women endure become opportunities of empowerment, but we have to listen to these painful stories before we can become empowered. Otherwise, women are simply taking for granted that the opportunities we have today have always been a given. And this, as is evidenced by Doña Antonia's story, has not always been the case.

\section{References}

Stravolemos, D. (1988). An act of heroism: A justification. Athens, Greece: Author. 
Mimica Tsezana Hyman, BA, is a Board member of the American Friends of the Jewish Museum of Greece in Newburgh, New York.

Alexander Katopis, MS, is a Lecturer and Field Placement Coordinator in Clinical Mental Health Counseling at the University of Southern Maine in Portland, Maine.

Susan Santiago, PhD, is a licensed Mental Health Counselor and Clinical Supervisor in private practice in Mountlake Terrace, Washington. 